\title{
The Acute Toxicity of Ki Hampelas Leaves (Sterculia rubiginosa Zoll. Ex Miq)
}

\author{
Rini Prastiwi*, Ema Dewanti, Cut Mauliza, Ester Hidayati, Ita Anggraini, Riska Anggraini, Vera Ladeska
}

Rini Prastiwi*, Ema Dewanti, Cut Mauliza, Ester Hidayati, Ita Anggraini, Riska Anggraini, Vera Ladeska

University of Mu-hammadiyah Prof. Dr. Hamka, Klender, Jakarta 13460, INDONESIA.

\section{Correspondence}

\section{Rini Prastiwi}

University of Muhammadiyah Prof.

Dr. HAMKA, Klender, Jakarta 13460 INDONESIA.

E-mail: khanzapras@gmail.com History

- Submission Date: 20-10-2020;

- Review completed: 27-11-2020;

- Accepted Date: 08-12-2020.

DOI : 10.5530/pj.2021.13.71

Article Available online

http://www.phcogj.com/v13/i2

\section{Copyright}

(C) 2021 Phcogi.Com. This is an openaccess article distributed under the terms of the Creative Commons Attribution 4.0 International license.

\section{ABSTRACT}

Background: Ki Hampelas (Sterculia rubiginosa Zoll. Ex Miq) is a medicinal plant with antioxidant and nephroprotective activity. Objective: This research aims to prove that Ki Hampelas leaves extract through an acute toxicity test. Materials and Methods: This study used white male rats of the Sprague-Dawley strain divided into four groups, the normal group and the $50 \mathrm{mg} /$ $\mathrm{kg}, 1000 \mathrm{mg} / \mathrm{kg}, 2000 \mathrm{mg} / \mathrm{kg}$ dose groups. For the acute toxicity test, a single dose with an observation of 14 days. After that, the surgery was done to see changes in the histopathology of the liver and kidneys. Results: The administration of Ki Hampelas leaf extract in the acute toxicity test did not cause death in the tested animals. There were no significant liver and kidney changes seen from the SGOT, SGPT, creatinine, urea, and histopathology. Conclusion: Ki Hampelas leaves extract did not cause death and toxic effects in the acute toxicity test. Key words: Ki Hampelas ( Sterculia rubiginosa Zoll. Ex Miq), Acute Toxicity, Liver, Kidney.

\section{INTRODUCTION}

Sterculia is a genus with many pharmacological activities and is also use as a material in pharmaceutical preparations. Among the genus, Sterculia, Sterculia villosa Roxb, has antileishmanial activity and a safety level at giving a non-toxic dose of $100 \mathrm{mg} / \mathrm{kg}$ body ${ }^{1}$. Sterculia setigera Del. has the activity of the ethanol extract of Sterculia setigera Del. has antioxidant activity with the DPPH method on the fruit of $91.81 \%$. In contrast, ethanol extract on stem bark is $86 \%^{2}$. Seeds of Sterculia foetida seed have antioxidant and antimicrobial activity ${ }^{3}$. Sterculia setigera Del., has activity as a tyrosinase inhibitory activity. It also has antiproliferative activity against human colon adenocarcinoma HT29. Sterulia quinqueloba (Garcke) K. Schum has activity as an antimycobacterial activity ${ }^{5}$. Sterculia quadrifida R.br Stem bark also has activity as an anti-hepatitis $\mathrm{C}^{6}$. Plants of the genus Sterculia are also using in $\mathrm{n}$ drug delivery applications ${ }^{7} . \mathrm{Ag}$ nanoparticles using seeds from Sterculia foetida L. have activity on mosquito vectors and HeLa cancer cells ${ }^{8}$. Some Sterculia genus plants have activities. Sterculia foetida for antibacterial and hemolytic $^{10}$, apoptosis ${ }^{11}$, Sterculia diversifolia for immunomodulatory and anti-cancer ${ }^{12}$, Sterculia villosa as fibrinolytic ${ }^{5}$, sedative ${ }^{6}$, Sterculia tragacantha as anti-inflammatory and analgesic ${ }^{15}$,

One of the plants used as an ingredient in traditional medicine is Ki Hampelas leaves (Sterculia rubiginosa Zoll. Ex Miq). These plants are scattered in tropical and subtropical areas, especially in Sumatra. Based on previous research, Ki Hampelas leaves contain tannins, flavonoids, alkaloids, steroids-terpenoids, glycosides, and phenols. The antioxidant activity and total flavonoids equivalent to quercetine ${ }^{17}$. So it is interesting to study whether Sterculia rubiginosa has antioxidant and nephroprotective activity ${ }^{16}$.
To ensure the safety, effectiveness, and quality of a drug must undergo a series of tests. Starting from screening to look for active compounds, then continued with testing the effectiveness or selectivity and its mechanism of action in experimental animals or microbes, after being declared to have certain pharmacological activities by a series of safety tests on experimental animals, the toxicity test ${ }^{17}$. In previous studies, Ki Hampelas leaves have activity as a nephroprotective and antioxidant with a minimum dose of $50 \mathrm{mg} / \mathrm{kg}^{16}$. So it is necessary to do a toxicity test to ensure the safety of Ki Hampelas leaves extract.

The acute toxicity test aims to detect toxic effects that appear quickly and determine the $\mathrm{LD}_{50}$ value in a compound or substance after being given a single dose or repeated doses within 24 hours.

\section{MATERIALS AND METHODS}

\section{Material}

The leaves of Ki Hampelas obtained from the Bogor Botanical Gardens, Indonesia. Determination at the Botanical Garden Plant Conservation Center, Botany Division, Biology Research Center-LIPI, Indonesia. Ethanol obtained from local suppliers. Urea reagent kit, Creatinine kit, SGOT kit, SGPT kit from PT. Human, Indonesia. Na CMC (PT. Brataco), aqua destillata, obtained from local suppliers.

\section{Extraction}

Ki Hampelas leaves powder was extracted by maceration method with $70 \%$ ethanol. Two hundred (200) grams of Simplicia powder by immersing $70 \%$ ethanol. Then concentrated using a vacuum rotary evaporator at a temperature of $50^{\circ} \mathrm{C}$ to obtain a thick extract, evaporated on a water bath with a temperature of $50^{\circ} \mathrm{C}$ until a viscous extract ${ }^{18}$.

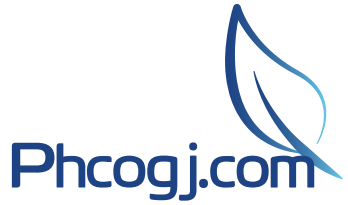

Cite this article: Prastiwi R, Dewanti E, Mauliza C, Hidayati E, Anggraini I, Anggraini R, et al. The Acute Toxicity of KI Hampelas Leaves (Sterculia rubiginosa Zoll. Ex Miq). Pharmacog J. 2021;13(2): 570-6. 


\section{Extract characteristics}

The extract was indentified with organoleptic, the yield, moisture content, ash content and phytochemical screening.

\section{Acute toxicity test}

Acute toxicity test used white male rats Sprague Dawley strain. The tested animals used in this study were 24 animals divided into four groups consisting of 6 animals for each group. The normal control group was given standard feed and $0.5 \% \mathrm{Na} C M C$, extract dose of $50 \mathrm{mg} / \mathrm{kg}$, $1000 \mathrm{mg} / \mathrm{kg}, 2000 \mathrm{mg} / \mathrm{kg}$. The test animals acclimatized for seven days. During acclimatization, the rats were fed and drunk and controlled the health and weight. Before taking blood, the animal test has fasted for \pm 12 hours. The animals anesthetized using ketamine intramuscularly, then blood serum samples taken from white rats. The liver's acute toxicity parameters determined by SGOT, SGPT, and histopathology of the central vein and pyknotic nucleus size. The kidneys' observation done by determining creatinine, urea, and histopathology by looking at the cast on the tubules and the percentage of tubules with close and glomerular swelling. Glomerular calculated by measuring the distance from the Bowman's capsule's edge to the glomerular rim $^{19}$. Tubular damage calculated using the formula $=(\mathrm{n} / \mathrm{m} \times 100 \%)$, where $\mathrm{n}=$ is the number of proximal tubules covered in one field of view and $\mathrm{m}=$ is the number of all proximal tubules in one field of view. Then the results were averaged to get the percentage of kidney damage in each mouse $^{20}$. This research was permitted by the Ethics Committee KEPKUHAMKA No. 02 / 20.03 / 0358.

\section{Data analysis}

The Kolmogorov-Smirnov and Levene's test determined the homogeneity and normal distribution of the data. The analytical continuous with the Tukey Test.

\section{RESULTS AND DISCUSSION}

\section{Phytochemical screening}

Flavonoids, glycosides, alkaloids, tannins, saponins, triterpenoids and steroids, are present in the extract. The test results show in Table 2.

Table 1: Quality Characteristics of extract S. rubiginosa.

\begin{tabular}{ccc}
\hline No. & Characteristics & Result \\
\hline & Organoleptic & \\
a.) Form & Thick extract \\
1. & b.) Color & Brownish green \\
& c.) Smell & Typical \\
2. & d.) Taste & A bit bitter \\
3. & Rendement & $13.19 \%$ \\
4. & Water content & $7.95 \%$ \\
\hline
\end{tabular}

Table 2: Phytochemical Screening of extract S. rubiginosa.

\begin{tabular}{cc}
\hline Chemical Ingredients & Result \\
\hline Alkaloids & + \\
Flavonoids & + \\
Tannins & + \\
Phenol & + \\
Saponins & - \\
Triterpenoi d \& Steroids & +
\end{tabular}

Description : $(+)=$ Presence; $(-)=$ Absence

\section{Acute toxicity of Ki hampelas leaf extract}

The results Ki Hampelas leaf extract with the highest dose of $2000 \mathrm{mg} /$ $\mathrm{kg}$ did not cause death in the test animals, the value of $\mathrm{LD}_{50}$ extract of Ki Hampelas leaves for test animals male white rats Sprague-Dawley is more than $2000 \mathrm{mg} / \mathrm{kg}$.

\section{Heart}

At SGOT levels, SGPT showed an increase between the normal group and the extract group. However, this increase is still in the normal range, so it concluded that Ki Hampelas leaves extract's giving does not influence it. From the results of examining SGOT and SGPT levels, the value obtained $(p>0.05)$ indicated no significant difference in each treatment group. The results show in Figures 1 and 2.

\section{Liver histopathology}

Histopathological observations of the liver include measuring the central vein's diameter and the number of pyknotic nuclei. The central vein's diameter is used in the measurement because the central venous area is the center of the hepatic lobule and part of the reservoir of blood originating from the hepatic artery and portal vein ${ }^{21}$. The results of liver histopathological preparations show in Figure 5.

The parameter of liver organ, the central vein's diameter, between normal and the test group, shows no difference between groups. This result show in figure 6 . The pyknotic nuclei show the differences between the normal and the test groups. Besides, the number of pyknotic nuclei which a sign of the occurrence of cell necrosis. This result show in Figure 7.

\section{Kidney}

The creatinine and urea levels of rats given the extract showed that treatment with different doses had increased creatinine and urea levels in rats. However, the increase in levels was still within normal limits. The results showed that creatinine and urea levels found that acute toxicity Ki Hampelas ki leaf extract had no significant effect on creatinine and urea levels $\mathrm{p}>0.05$. The results show in figures 3 and 4 .

\section{Kidney histopathology}

Observations on the structure of the kidney structure include the distance between the glomerulus and Bowman's capsule, the percentage of tubules that close in one view and the cast on the tubules, can be seen in Figure 8. Casts are a collection of proteins that result in channeling through the tubular renal hampered, also stimulate the occurrence of necrosis

of the tubules. While necrosis is death Jarin gan due to the absence of metabolites ${ }^{22}$.

The result of the study showed no presence of cast in control normal and the test groups. The percentage of tubules that closed in one field of view showed that there was no significant difference between the normal group and the $50 \mathrm{mg} / \mathrm{kg}$ dose group $\mathrm{p}>0.05$, and the results between the $1000 \mathrm{mg} / \mathrm{kg}$ dose group and the $2000 \mathrm{mg} / \mathrm{kg}$ dose test group not seen. The significant difference with $\mathrm{p}>0.05$ shown in Figure 9. Meanwhile, the bowman room distance shows a significant difference between the normal control and test groups. The result show in Figure 10.

\section{CONCLUSION}

The ethanol extract of $70 \% \mathrm{Ki}$ Hampelas leaves in the acute toxicity test did not cause death and toxic effects. The examination of SGOT and SGPT levels showed no significant difference between the dose treatment group and the normal group $(\mathrm{p}>0.05)$. 


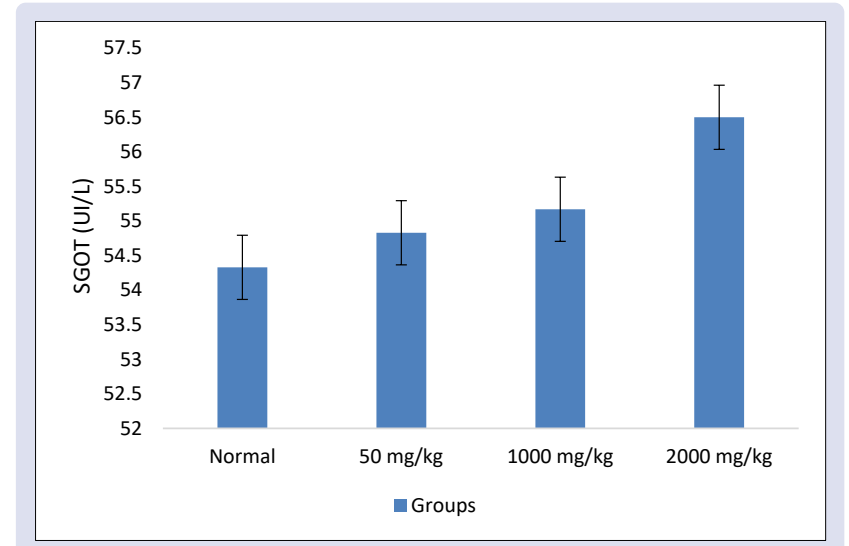

Figure 1: The SGOT Serum.

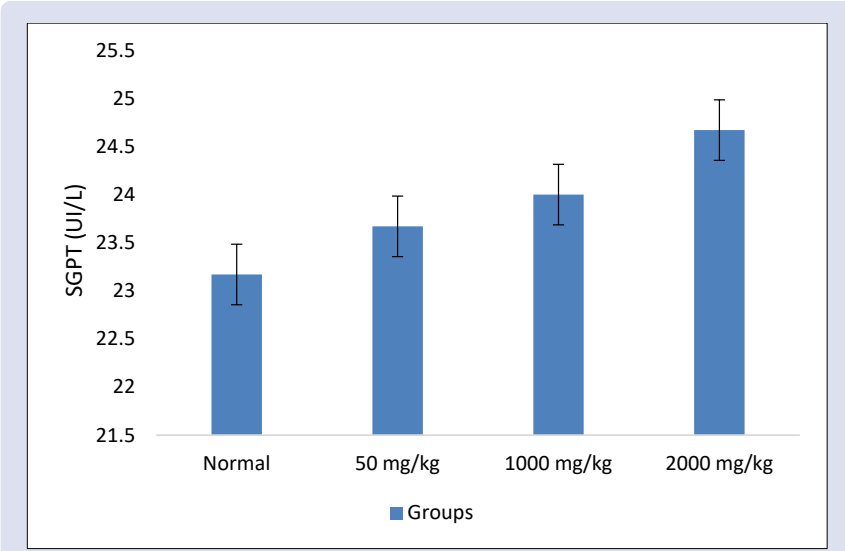

Figure 2: The SGPT Serum.

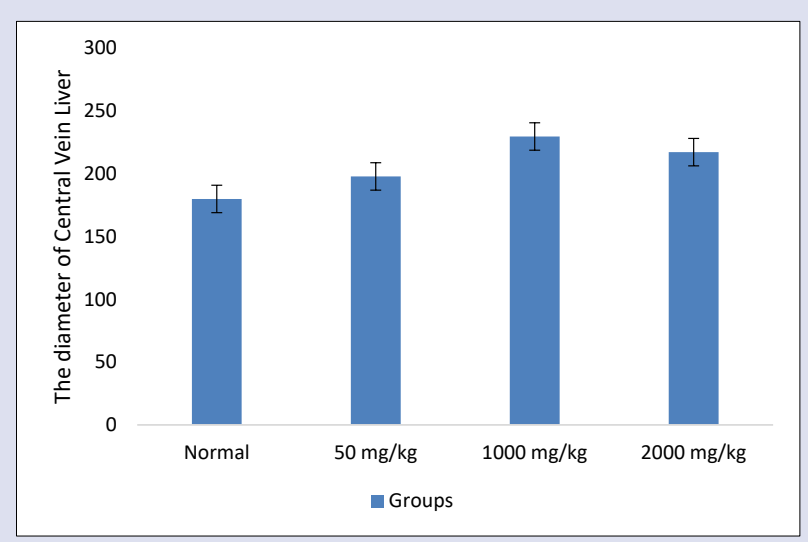

Figure 4: The diameter of Central Vein Liver.

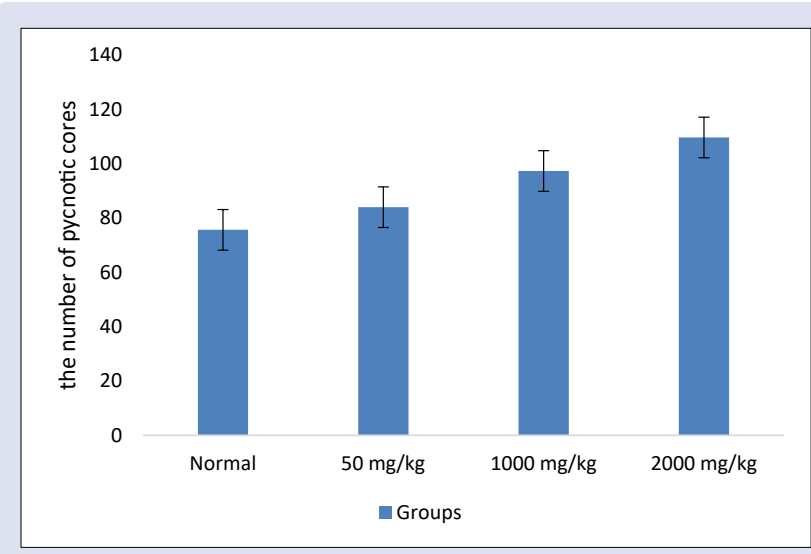

Figure 5: The Number of Pycnotic Cores.

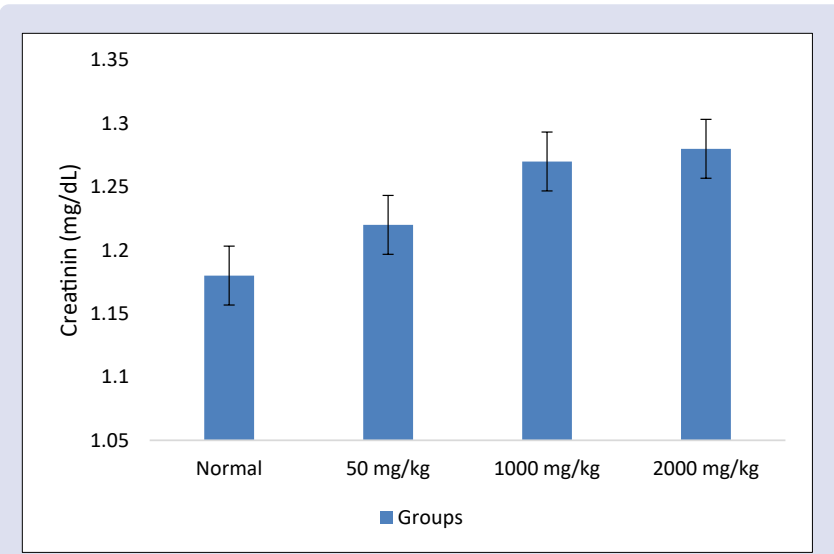

Figure 6: The Creatinine Serum.
Figure 3: The histopathology of liver. (A) Normal control 0:5\% CMC, (B) 50 $\mathrm{mg} / \mathrm{kg}$, (C) $1000 \mathrm{mg} / \mathrm{kg}$, and (D) $2000 \mathrm{mg} / \mathrm{kg}$.
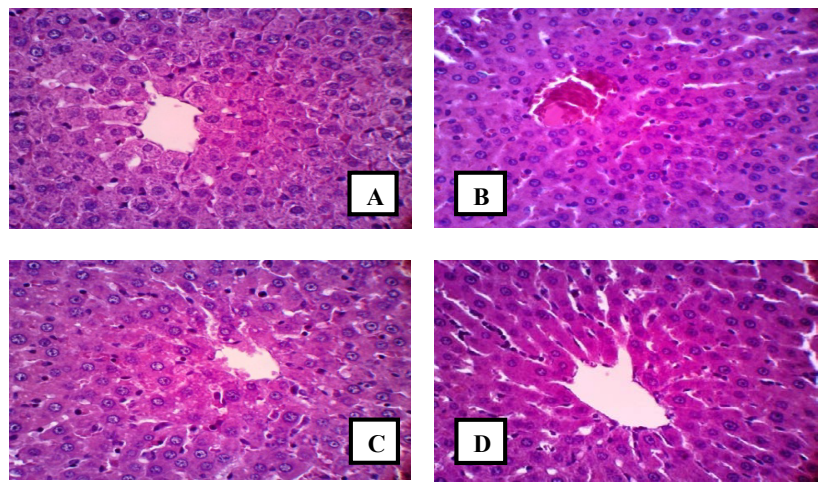


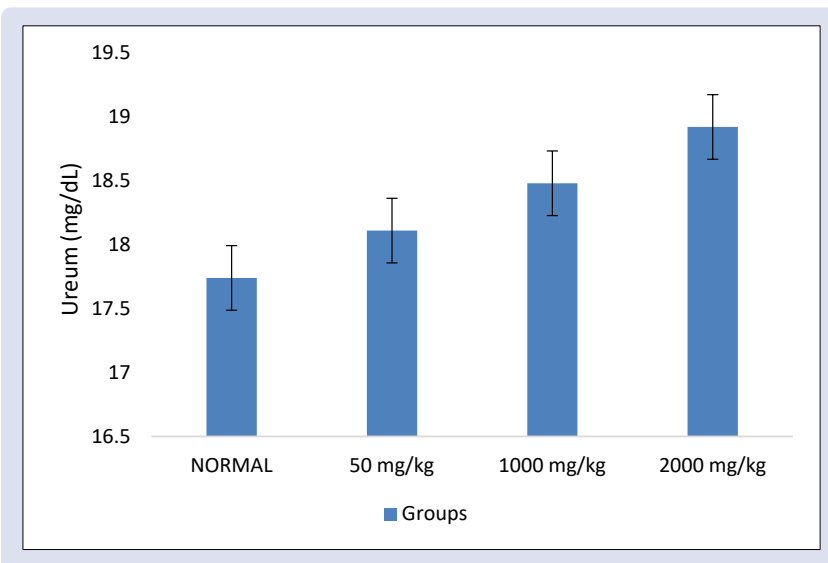

Figure 7: Ureum levels.
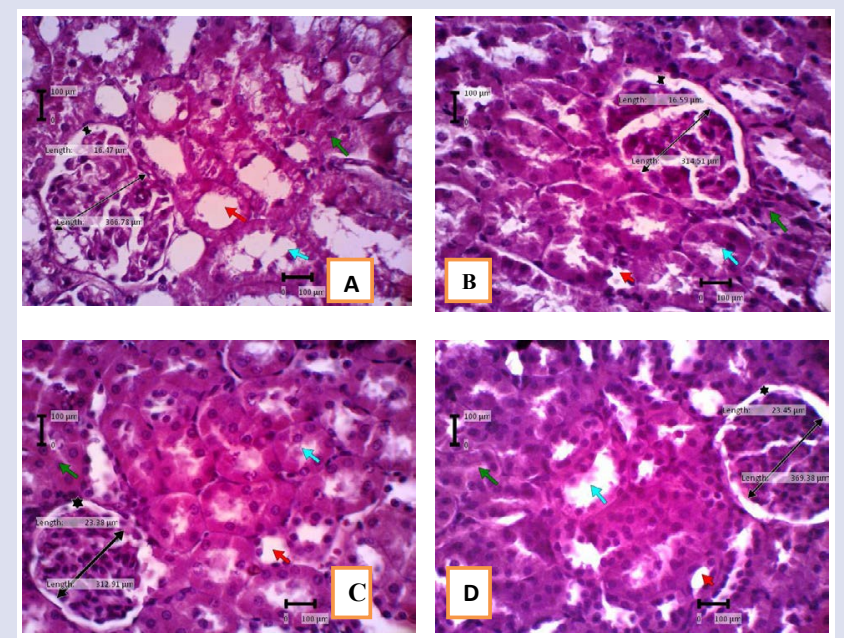

Figure 8: The Histopatology of Kidney. (A) Normal CMC 0,5\%, (B) 50 $\mathrm{mg} / \mathrm{kg}$, (C) $1000 \mathrm{mg} / \mathrm{kg}$, dan (D) $2000 \mathrm{mg} / \mathrm{kg}$.

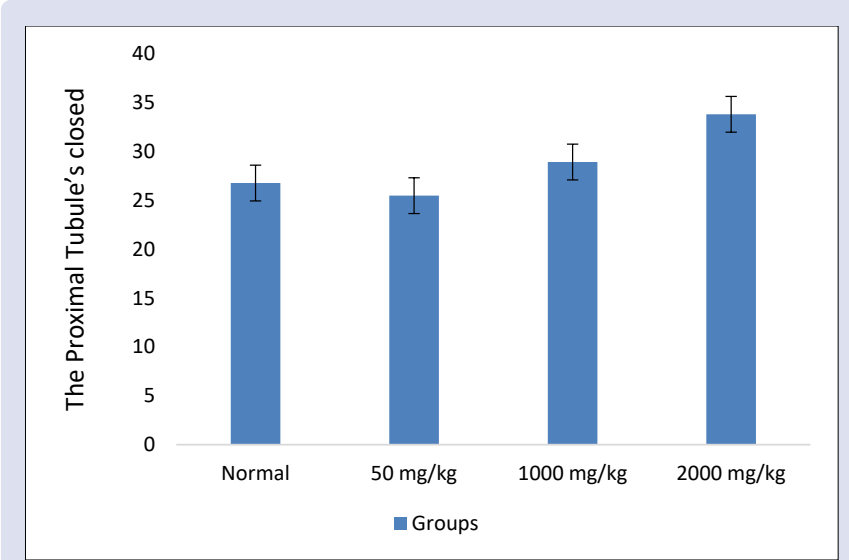

Figure 9: The Proximal Tubule's closed.

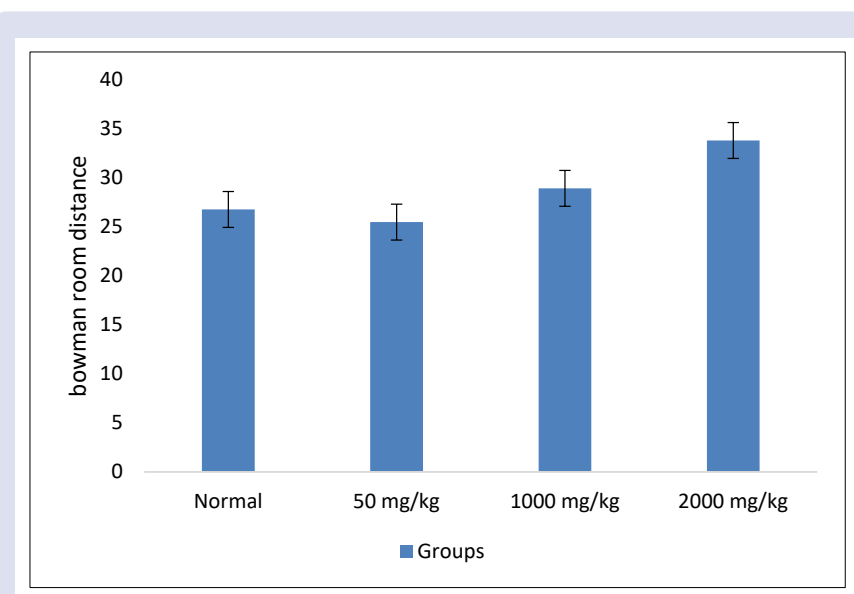

Figure 10: Kidney Bowman's Space Distance.

\section{ETHICAL ISSUES}

The Ethics Committee permitted this research with the number KEPKUHAMKA No. 02 / 20.03 / 0358.

\section{CONFLICTS OF INTEREST}

All authors state there is no conflicts of interest.

\section{ACKNOWLEDGMENT}

The author would like to thank the Ministry of Research, Technology, and Higher Education, The Republic of Indonesia, for the Research Foundation through the PDUPT Grant.

\section{REFERENCES}

1. A. Das, M. C. Das, N. Das, and S. Bhattacharjee, Evaluation of the antileishmanial potency, toxicity and phytochemical constituents of methanol bark extract of Sterculia villosa. Pharm Biol. 2017:55(1):9981009.

2. N. M. M. Taha and B. M. Mudawi, Antioxidant and Cytotoxic Activities of Sterculia setigera Del American journal of Research Communication. 2018;6(5):41-9.

3. A. Jafri, S. Bano, J. Rais, F. Khan, N. Shivnath. Phytochemical screening of Sterculia foetida seed extract for anti-oxidant, anti-microbial activity, and detection of apoptosis through reactive oxygen species ( ROS ) generation, mitochondrial membrane potential ( MMP ) decrease, and nuclear fragmentation in human osteosarcoma cells. J. Histotechnol. 209:42(2):1-12.

4. E. S. M. Bahnson, N. Koo, N. Cantu-medellin, A. Y. Tsui, G. E. Havelka, J. M. Vercammen, Q. Jiang, E. E. Kelley, et al. Nitric Oxide Nitric oxide inhibits neointimal hyperplasia following vascular injury via differential, cell-specific modulation of SOD-1 in the arterial wall. Nitric Oxide. 2015:44;8-17.

5. E. Wilson, M. Chacha, and J. Omolo. In vitro Antimycobacterial Activity of Sterculia quinqueloba ( Garcke) K. Schumand Canthium crassum Hiern. European Journal of Medicinal Plants. 2015:6(2);1039.

6. M. Ayu, W. Moi, A. A. Permanasari, M. Adianti, and L. Tumewu. The Activity of Sterculia quadrifida $\mathrm{R}$. br Stembark against Hepatitis $C$ Virus. In Proceedings of BROMO Conference (BROMO 2018). 2018:106-10. 
7. H. Bera, Y. F. Abbasi, S. Hasnain, and A. K. Nayak, Chapter 9 - Sterculia gum in drug delivery applications. Elsevier Inc., 2019:227-45.

8. P. Rajasekharreddy and P. U. Rani. Biofabrication of Ag nanoparticles using Sterculia foetida $L$. seed extract and their toxic potential against mosquito vectors and HeLa cancer cells. Mater. Sci. Eng. C. 204:39:203-12

9. R. Prastiwi, B. Elya, R. Sauriasari, M. Hanafi, and E. Dewanti. Pharmacognosy, Phytochemical Study and Antioxidant Activity of Sterculia rubiginosa Zoll. Ex Miq. Leaves. Pharmacognosy Journal. 2018;10:571-5.

10. A. Braga and R. Rodrigues, Gracy, Gregorio, Hilzet, et al. Antibacterial and Hemolytic Activity of a new Lectin Purified from the Seeds of Sterculia Foetida L . Appl Biochem Biotechnol. 2015;175:1689-99.

11. Jafri, S. Bano, J. Rais, F. Khan, and N. Shivnath. Phytochemical screening of Sterculia foetida seed extract for antioxidant, antimicrobial activity, and detection of apoptosis through reactive oxygen species ( ROS ) generation, mitochondrial membrane potential (MMP ) decrease, and nuclear fragmentation in human osteosarcoma cells. J. Histotechnol. 2019:1-12.

12. N. and I. U. Fazle Rabbi, Amir Zada, Achyut Adhikari, Almas Jabeen. Sterculia diversifolia bears anti-cancer and immunomodulatory activities. Bangladesh J. Pharmacol. 2017;12:52-5.

13. Z. Uddin, T. Bin Emran, A. K. Nath, I. Hossain, M. Alamgir, and S. Rana. In vitro Antioxidative, Fibrinolytic and Phytochemical Effects of Different Extracts of Sterculia villosa Barks. Int. J. Res. Pharm. Biosci. 2015;2:1-9.
14. F. Hossain, B. Talukder, M. N. Rana, R. Tasnim, T. S. Nipun, S. M. N. Uddin, and S. M. M. Hossen. In vivo sedative activity of methanolic extract of Sterculia villosa Roxb . leaves. BMC Complement. Altern. Med. 2016;16:10-3.

15. O. M. Mogbojuri, A. A. Adedapo, and M. O. Abatan. Phytochemical screening, safety evaluation, anti-inflammatory and analgesic studies of the leaf extracts of Sterculia tragacantha. J Complement Integr Med. 2016:2-7.

16. R. Prastiwi, E. Dewanti, I. Nurul, N. Aqilla, S. Salsabila, and V. Ladeska. The Nephroprotective And Antioxidant Activity of Sterculia rubiginosa Zoll. Ex Miq. Leaves . Pharmacognosy Journal. 2020;12:843-9.

17. Priyanto. Toxicology, Mechanism, Antidote Therapy, and Risk Assessment. Lenskofi. Indonesia. 2009.

18. Depkes RI. Indonesian Herbal Pharmacopoeia Edition 1. Ministry of Health RI. Indonesia. 2008.

19. Cahyaningsih. Nephroprotective Effect of Breadfruit Leaf Infusion Artocarpusaltilis Park. Fsb. On Carbon Tetrachloride Induced Male Rats. Pharmaceutical Science Magazine. 2011:15-73.

20. Sihardo. The Effect of Pandanus conoideus Oil on Kidney Histology in Swiss Mice Infection with Plasmodium bergehei Anka. Scientific Writing. 2006.

21. Mescher. Basic Histology of the Junqueira Text and Atlas. EGC. Jakarta. 2011.

22. I. Fajriaty, I. Hariyanto, I. Saputra, and M. Silitonga. Phytochemical Screening and Thin Layer Chromatography Analysis of Ethanol Extract of Lerak Fruit (Sapindus rarak). Journal of Informatics and Science Education. 2017;6:243-56.

\section{GRAPHICAL ABSTRACT}
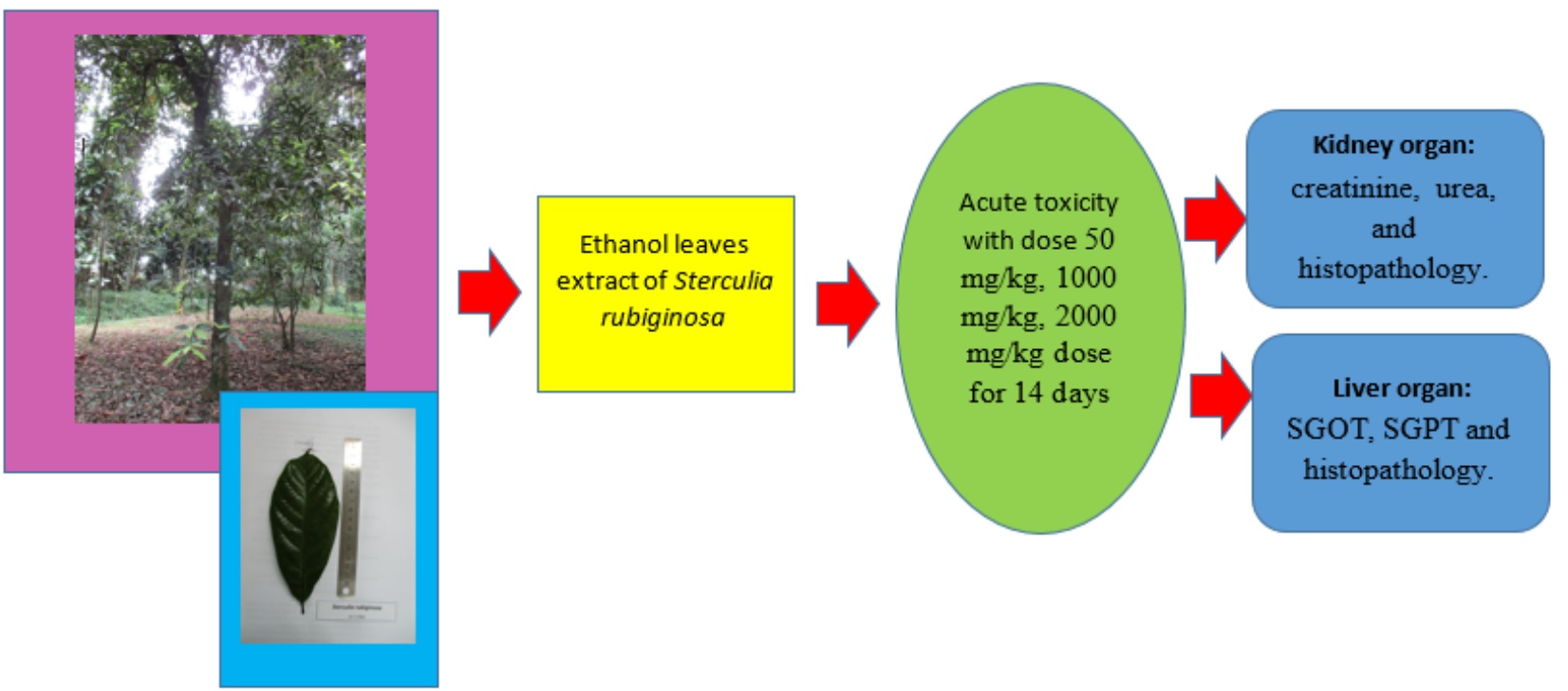


\section{ABOUT AUTHORS}

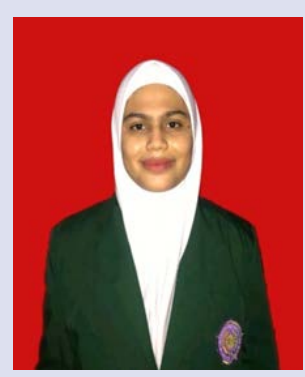

Cut Mauliza: Student at Faculty of Pharmacy and Sciences, University of Muhammadiyah Prof. Dr. HAMKA, Klender, Jakarta 13460, Indonesia.

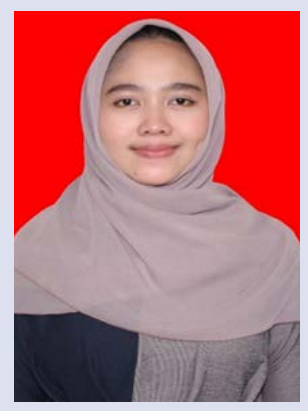

Ita Anggraini: Student at Faculty of Pharmacy and Sciences, University of Muhammadiyah Prof. Dr. HAMKA, Klender, Jakarta 13460, Indonesia.

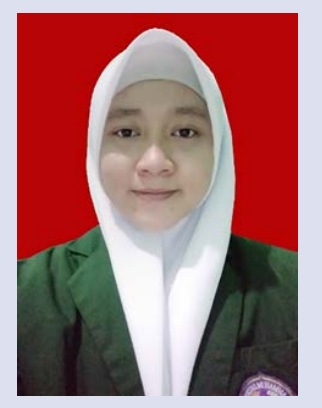

Riska Anggraini: Student at Faculty of Pharmacy and Sciences, University of Muhammadiyah Prof. Dr. HAMKA, Klender, Jakarta 13460, Indonesia.

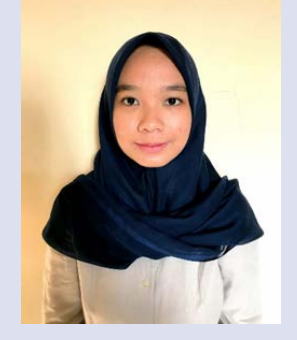

Ester Hidayati: Student at Faculty of Pharmacy and Sciences, University of Muhammadiyah Prof. Dr. HAMKA, Klender, Jakarta 13460, Indonesia.

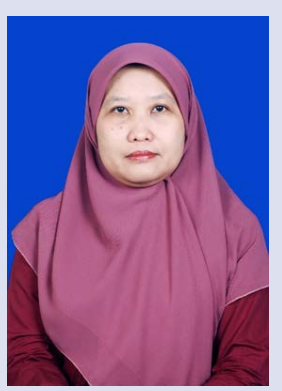

Ema Dewanti: Lecturer and researcher at Faculty of Pharmacy and Sciences, University of Muhammadiyah Prof. Dr. HAMKA, Klender, Jakarta 13460, Indonesia. 


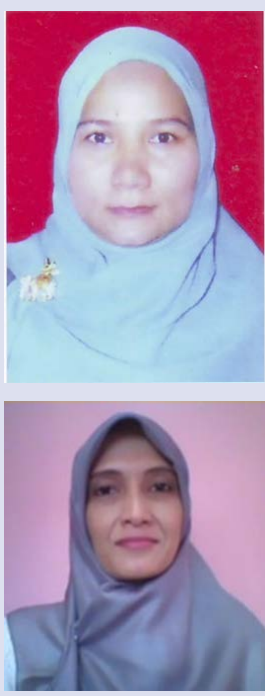

Vera Ladeska: Lecturer and researcher at Faculty of Pharmacy and Sciences, University of Muhammadiyah Prof. Dr. HAMKA, Klender, Jakarta 13460, Indonesia.

Rini Prastiwi: Lecturer and researcher at Faculty of Pharmacy and Sciences, University of Muhammadiyah Prof. Dr. HAMKA, Klender, Jakarta 13460, Indonesia.

Cite this article: Prastiwi R, Dewanti E, Mauliza C, Hidayati E, Anggraini I, Anggraini R, et al. The Acute Toxicity of KI Hampelas Leaves (Sterculia rubiginosa Zoll. Ex Miq). Pharmacog J. 2021;13(2): 570-6. 